\title{
Myocarditis complicating cytomegalovirus mononucleosis
}

\author{
S. G. BALL \\ M.A., M.B., B.Chir., M.R.C.P. \\ G. J. ARCHER \\ M.B., Ch.B., M.R.C.P. \\ Department of Medicine, Leeds General Infirmary, Great George Street, Leeds 1
}

\begin{abstract}
Summary
A case of cytomegalovirus mononucleosis with myocarditis as the major presenting clinical manifestation is described. The rarity of symptomatic myocarditis in this condition is discussed.
\end{abstract}

\section{Introduction}

Myocarditis is an unusual feature of cytomegalovirus mononucleosis. When it occurs it is usually a minor part of the clinical syndrome, and may be recognized by transient changes in the electrocardiogram (Klemola et al., 1967; Klemola, 1973).

\section{Case history}

A 34-year-old nurse was admitted to hospital complaining of the sudden onset of shortness of breath associated with a tight feeling in the chest. For a week before admission she had felt generally unwell with headache and muscle aches, and had been largely confined to bed. She had been taking an oral contraceptive regularly for two years.

On admission she was sweating and dyspnoeic; her temperature was $37^{\circ} \mathrm{C}$. There was a tachycardia, $140 / \mathrm{min}$. The jugular venous pressure was not raised. There was a triple rhythm but no murmurs and no pericardial rub. The lungs were normal clinically. There was no evidence of deep vein thrombosis. The liver and spleen were not enlarged, and no abnormal lymph nodes were found. The chest X-ray was normal. The electrocardiagram showed a sinus tachycardia with an 'S1 Q3 T3' pattern. The electrical axis was normal and there were no $T$ wave changes in the right precordial leads V1-V3 (Fig. 1).

An initial diagnosis of pulmonary embolism was made. Heparin therapy was started with $10,000 \mathrm{u}$ given intravenously and then $15,000 \mathrm{u}$ in $500 \mathrm{ml}$ of $5 \%$ dextrose 12 -hourly. During the next $24 \mathrm{hr}$ her temperature rose to $38.5^{\circ} \mathrm{C}$ but otherwise her condition remained unchanged.

The initial white cell count was $7200 / \mathrm{mm}^{3}$ with $68 \%$ neutrophils, $19 \%$ lymphocytes, $9 \%$ monocytes, and $2 \%$ atypical mononuclear cells. The E.S.R. was $98 \mathrm{~mm}$ in the first hour. The chest X-ray was repeated the next day and again appeared normal.
At this time further electrocardiographic changes $\stackrel{\omega}{\sigma}$ developed, with $Q$ wave formation and $T$ wavec inversion in lead aVF (Fig. 2).

A revised diagnosis of probable viral myocarditis was made. Subsequent investigations are summarized $\delta$ in Table 1, where it can be seen that serial cyto- $\AA$ megolavirus titres from blood were high and re- $\overrightarrow{0}$ mained raised for a number of weeks. The titres of $N$ antibodies to the Coxsackie group of viruses and to을 Toxoplasma were not raised. Cytomegalovirus was not isolated from throat swabs, faeces or urine. The $\mathbb{\Phi}$ serum enzymes which were markedly elevated $24 \mathrm{hr}$ 을 after admission returned to normal values within 21 days. The electrocardiogram 3 weeks after admission showed some resolution of the earlier $\vec{\varphi}$ changes (Fig. 3).

For 11 days the patient had a remittent fever of 눙ㅁำ to $39^{\circ} \mathrm{C}$ which subsided by the sixteenth day. S However, tachycardia (100/min) persisted for a further 4 days. One month after admission the patient was discharged home feeling well.

\section{Comment}

The patient's symptoms, the changes in the electrocardiograms, the blood picture, and the very high cytomegalovirus titres confirm a diagnosis of cytomegalovirus mononucleosis complicated by myocarditis.

Cytomegalovirus infection is common if judged by antibody titres; in one series $54 \%$ of the population had positive titres by the age of 35 (Stern and Elek, 1965). Cytomegalovirus infection in adults is often 음 asymptomatic, but an infectious mononucleosis- $\rightarrow$ like syndrome is not uncommon. The patient presents with a febrile illness resembling infectious $N$ mononucleosis but with a negative heterophil ${ }^{\circ}$ antibody test. There is usually no lymphadenopathy (Klemola et al., 1969; Klemola and Kaariainen, $\mathfrak{\omega}$ 1965). Uncommonly, liver and spleen have been reported to be enlarged (Klemola, 1973; Jordanco et al., 1973; Herlong and Esham, 1973). Jaundice is rare although abnormal liver function tests are $\stackrel{?}{+}$ common. Cytomegalovirus mononucleosis may occur 70 following blood transfusion (Klemola et al., 1969). 


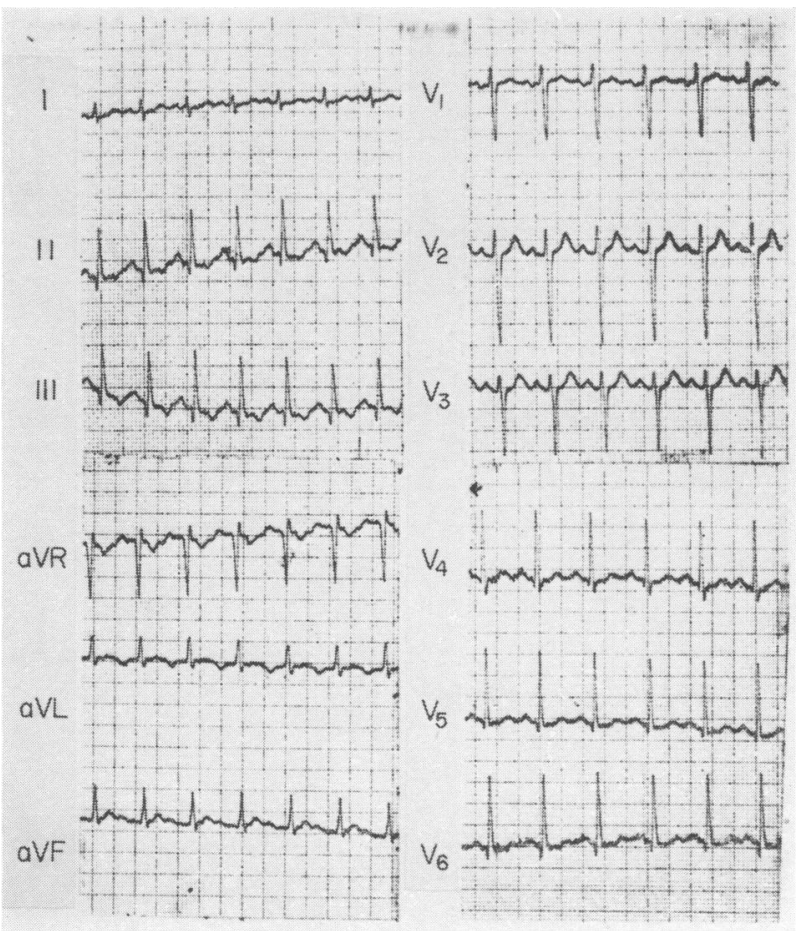

FIG. 1. Electrocardiogram on admission.

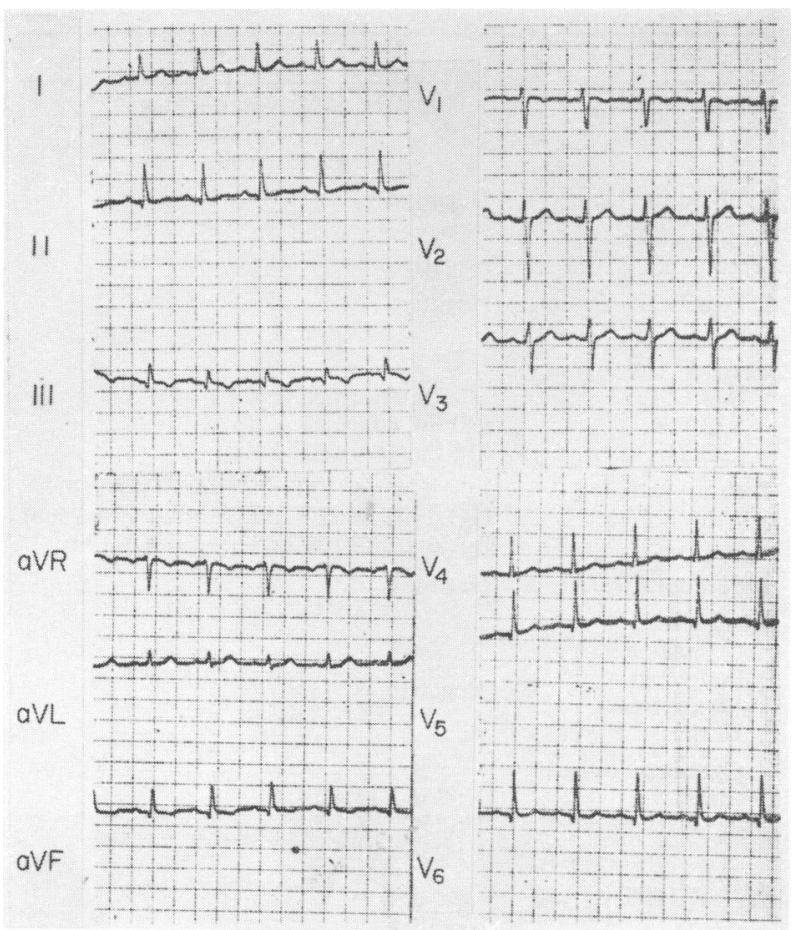

FIG. 2. Electrocardiogram two days after admission. 


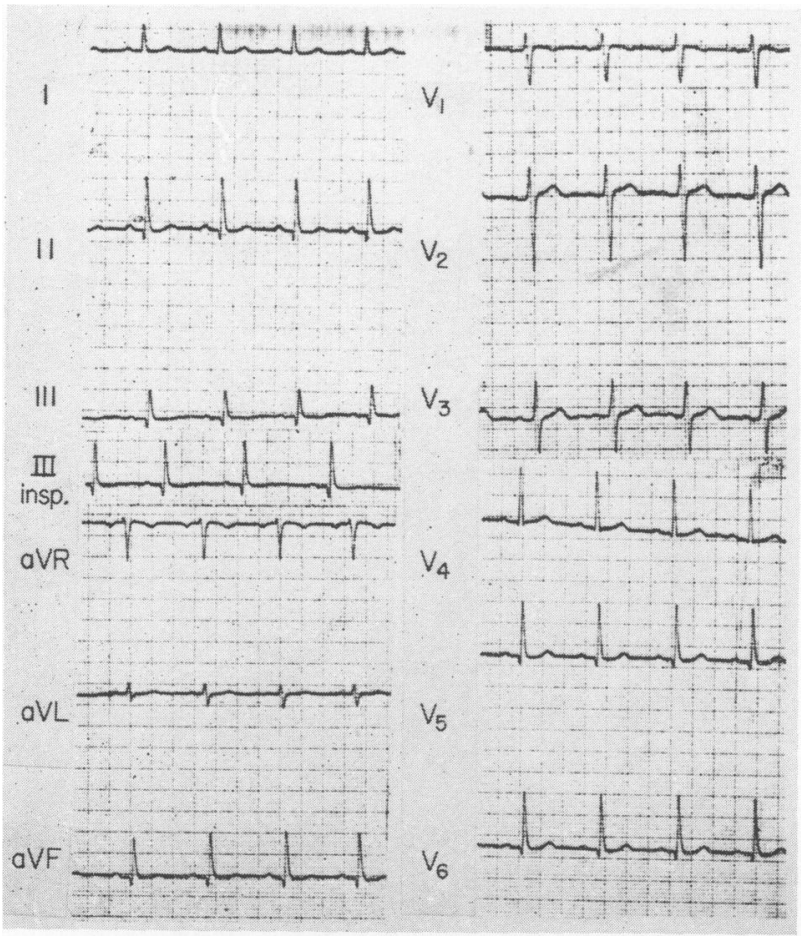

Fig. 3. Electrocardiogram three weeks after admission.

TABLE 1. Summary of the relevant investigations and results

\begin{tabular}{|c|c|c|}
\hline Test & & Result \\
\hline White cell count & $8600 / \mathrm{mm}^{3}$ & $\begin{array}{l}55 \% \text { lymphocytes } \\
8 \% \text { atypical mono- } \\
\text { nuclear cells }\end{array}$ \\
\hline Paul-Bunnell & Negative & \\
\hline $\begin{array}{l}\text { Anti-nuclear } \\
\text { factor }\end{array}$ & Negative & \\
\hline L.E. cells & Negative & \\
\hline $\begin{array}{l}\text { Liver function } \\
\text { tests:- } \\
\text { S.G.O.T. } \\
\text { S.G.P.T. } \\
\text { L.D.H. }\end{array}$ & $\begin{array}{l}88 \text { i.u. (nc } \\
140 \text { i.u. (n } \\
618 \text { i.u. (n }\end{array}$ & $\begin{array}{l}\text { ormal }<20 \text { ) } \\
\text { ormal }<20 \text { ) } \\
\text { ormal }<400 \text { ) }\end{array}$ \\
\hline Serum proteins & $\begin{array}{l}\operatorname{IgM~} 600 \mathrm{~m} \\
\operatorname{IgG~} 2000 \mathrm{r} \\
\text { IgA } 300 \mathrm{~m}\end{array}$ & $\begin{array}{l}\mathrm{ng} / 100 \mathrm{ml}(\text { normal } 40-260) \\
\mathrm{mg} / 100 \mathrm{ml}(\text { normal } 700-1500) \\
\mathrm{g} / 100 \mathrm{ml} \text { (normal } 60-190)\end{array}$ \\
\hline Blood cultures & Negative & \\
\hline $\left.\begin{array}{l}\text { Viral screen:- } \\
\text { Coxsackie } \\
\text { Echovirus } \\
\text { Myxoviruses } \\
\text { Herpes }\end{array}\right\}$ & Negative & \\
\hline $\begin{array}{l}\text { Cytomegalovirus } \\
\text { titres }\end{array}$ & $\begin{array}{l:l}1: 256 & 1 \\
1: 256 & \\
1: 256 & 2\end{array}$ & $\begin{array}{l}3.4 .74 \\
4.5 .74 \\
1.5 .74\end{array}$ \\
\hline Mycoplasma & & \\
\hline $\left.\begin{array}{l}\text { Coxiella } \\
\text { Toxoplasma }\end{array}\right\}$ & Negative & \\
\hline
\end{tabular}


The condition is usually mild and has a good prognosis.

Generalized cytomegalovirus infection has been associated with a fatal case of myocarditis in a 15year-old boy (Tiula and Leinikki, 1972). Evidence of myocardial involvement by the virus has been found at autopsy in a further case (Vogel, 1958). Myocarditis has been inferred from the changes in the electrocardiograms of two out of fourteen cases of cytomegalovirus infection in older children and young adults (Sterner et al., 1970). A patient with associated hepatitis and pericarditis has been described (Rasanen and Saikku, 1967).

Myocarditis has occasionally been inferred from the presence of electrocardiographic changes in cases of cytomegalovirus mononucleosis (Klemola, 1973; Klemola et al., 1967). Myocarditis as the major presenting clinical manifestation does not appear to have been previously reported.

\section{Acknowledgments}

We wish to thank Professor G. P. McNicol for allowing us to publish this case, Dr M. R. Lee and Professor G. P. McNicol for their advice, and Dr E. H. Hambling, Department of Virology, Public Health Laboratories, Leeds, for his help with the serological tests.

\section{References}

Herlong, W.B. \& Esham, R.H. (1973) Asymptomatic cytomegalovirus mononucleosis. Annals of Internal Medicine, 79, 756.
Jordan, M.C., Rousseau, W.E., Stewart, J.A., Noble, G.R. \& ChIN, T.D.Y. (1973) Spontaneous cytomegalovirus mononucleosis-clinical and laboratory observations in nine cases. Annals of Internal Medicine, 79, 153.

KLEMOLA, E. (1973) Cytomegalovirus infection in previously healthy adults. Annals of Internal Medicine, 79, 267.

Klemola, E. \& KaARIAINEN, L. (1965) Cytomegalovirus as a possible cause of a disease resembling infectious mononucleosis. British Medical Journal, 2, 1099.

Klemola, E., KaAriainen, L., von Essen, R., Haltia, K., KoIvUniemi, A. \& voN BondSDORFF, C.H. (1967) Further studies on cytomegalovirus mononucleosis in previously healthy individuals. Acta medica scandinavica, 182, 311.

Klemola, E., von Essen, R., Wager, O., Haltia, K., Koivuniemi, A. \& SAlmi, I. (1969) Cytomegalovirus in previously healthy individuals-five new cases and followup of thirteen previously published cases. Annals of Internal Medicine, 71, 11.

RASANEN, V. \& SAIKKu, P. (1967) Cytomegalovirus hepatitis. Lancet, ii, 772.

SterN, H. \& Elek, S.D. (1965) The incidence of infection with cytomegalovirus in a normal population. Journal of Hygiene, 63, 79.

Sterner, G., Agell, B., Wahren, B. \& Espmark, A. (1970) Acquired cytomegalovirus infection in older children and adults. Scandinavian Journal of Infectious Diseases, 2, 95.

Tiula, E. \& LeinikKI, P. (1972) Fatal cytomegalovirus infection in a previously healthy boy with myocarditis and consumption coagulopathy as presenting signs. Scandinavian Journal of Infectious Diseases, 4, 57.

VOGEL, S. (1958) Enhanced susceptibility of proliferating endothelium to salivary gland virus under naturally occurring and experimental conditions. American Journal of Pathology, 34, 1069. 